NBER WORKING PAPER SERIES

\title{
THE MOST IMPORTANT WORKS OF ART OF THE TWENTIETH CENTURY
}

David W. Galenson

Working Paper 12058

http://www.nber.org/papers/w12058

\author{
NATIONAL BUREAU OF ECONOMIC RESEARCH \\ 1050 Massachusetts Avenue \\ Cambridge, MA 02138 \\ February 2006
}

The views expressed herein are those of the author(s) and do not necessarily reflect the views of the National Bureau of Economic Research.

(C2006 by David W. Galenson. All rights reserved. Short sections of text, not to exceed two paragraphs, may be quoted without explicit permission provided that full credit, including () notice, is given to the source. 
The Most Important Works of Art of the Twentieth Century

David W. Galenson

NBER Working Paper No. 12058

February 2006

JEL No. J0, J4

\begin{abstract}
$\underline{\text { ABSTRACT }}$
A survey of art history textbooks identifies and ranks the eight most important works of the 20th century. The most important painting of the century was Les Demoiselles d'Avignon, executed by Picasso at the age of 26, which began the development of Cubism. Among the other seven works, a collage, an earthwork, and a ready-made all represent new genres that had not existed at the start of the century. All eight works were made by conceptual artists, at a median age of just 32 . The results underline the importance of young conceptual innovators, who made radical departures from existing conventions, in the advanced art of the century. Four of the eight works were made by Picasso and Marcel Duchamp, and this highlights the importance of the versatile conceptual innovators who became a prominent feature of twentieth-century art.

David W. Galenson

Department of Economics

University of Chicago

1126 East 59th Street

Chicago, IL 60637

and NBER

dgalenson@uchicago.edu
\end{abstract}


Introduction

Quality in art is not just a matter of private experience. There is a consensus of taste.

Clement Greenberg ${ }^{1}$

Important works of art embody important innovations. The most important works of art are those that announce very important innovations.

There is considerable interest in identifying the most important artists, and their most important works, not only among those who study art professionally, but also among a wider public. The distinguished art historian Meyer Schapiro recognized that this is due in large part to the market value of works of art: "The great interest in painting and sculpture (versus poetry) arises precisely from its unique character as art that produces expensive, rare, and speculative commodities." 2 Schapiro's insight suggests one means of identifying the most important artists, through analysis of prices at public sales. ${ }^{3}$ This strategy is less useful in identifying the most important individual works of art, however, for these rarely, if ever, come to market.

An alternative is to survey the judgments of art experts. One way to do this is by analyzing textbooks. The illustrations an author chooses implicitly tell us which works of art he considers most valuable in providing a narrative of the successive innovations that make up the history of art. Surveying a large number of textbooks effectively allows us to poll art historians as to which works are generally considered the most essential to this narrative. This study will identify and rank the individual works that authors of recent textbooks consider the most important ones of the twentieth century. We will then consider why each of these works is significant, and what common elements they share. The results are surprising in a number of respects; understanding why this is the case will contribute to a richer understanding of the art of 
the past century.

The Ranking

In the last analysis, the artist may shout from the rooftops that he is a genius; he will have to wait for the verdict of the spectator in order that his declarations take a social value and that, finally, posterity includes him in the primers of Art History.

Marcel Duchamp ${ }^{4}$

The data collection for the present study can begin from the results of a series of earlier surveys of textbooks. Each of these earlier studies ranked the most important artists and works of art made at specific times and places throughout the twentieth century. In all, eight individual works of art were found to have been illustrated in at least half of all the books surveyed in one or more of these earlier studies. ${ }^{5}$ These eight works are listed in chronological order in Table 1.

The specific textbooks used in each of the earlier studies varied, since some books did not cover the relevant times and places considered by some of those studies. To obtain a consistent ranking of the eight works listed in Table 1, this study consequently required a new survey, in which none of the textbooks analyzed excluded any of the eight works due to the book's specified coverage. A total of 33 books were found that were published since 1990 and covered all relevant genres of art during the entire period from the earliest to the latest dates in Table $1 .^{6}$

Table 2 presents the results of this new survey. Picasso's Les Demoiselles d'Avignon ranks first, illustrated in $85 \%$ of the textbooks surveyed. Understanding why it is the most essential work of art of the twentieth century, and why the other seven works in the table are also central to narratives of art history, requires us to consider each individually. The following sections of this paper take up each work in turn, in the order of their production. 


\section{Les Demoiselles d'Avignon, 1907}

Picasso studies an object like a surgeon dissecting a corpse.

Guillaume Apollinaire, $1913^{7}$

Les Demoiselles d'Avignon is clearly the most important painting of the $20^{\text {th }}$ century.

With its execution, the greatest artist of the century initiated the century's most important artistic movement. Art scholars debate whether the Demoiselles should be considered a Cubist painting, but there is no question that it differed profoundly from all of the art that preceded it, and that it began the development of Cubism. Nor is there any debate over the painting's importance, as for example George Heard Hamilton observed that "it has been recognized as a watershed between the old pictorial world and the new," and John Russell described it as "the white whale of modern art: the legendary giant with which we have to come to terms sooner or later."

The Demoiselles was intended to be a masterpiece. Stung by the success his rival, Henri Matisse, had gained by exhibiting his large Fauve manifesto Le Bonheur de vivre in the spring of 1906, later that year Picasso began to fill one sketchbook after another with preparatory drawings for his own large masterpiece. ${ }^{9}$ William Rubin concluded that in all Picasso made between 400 and 500 studies for the Demoiselles - "a quantity of preparatory work unique not only in Picasso's career, but without parallel, for a single picture, in the entire history of art." ${ }^{10}$ More than 60 square feet in size, the painting was by far the largest Picasso had ever attempted. ${ }^{11}$

The Demoiselles announced Cubism's rejection of linear perspective, which had dominated Western art since the Renaissance, and anticipated the new representation of space and construction of form that would characterize the Cubist revolution. The painting's radical formal innovations combined with its thorough disregard for conventional standards of beauty to 
jolt the advanced art world: not only did Matisse denounce the painting as an attempt to discredit modern art, but even Georges Braque, who would later join forces with Picasso in developing Cubism, was initially so shocked by the painting that he compared Picasso to the fairground fireeaters who drank kerosene to spit flames. ${ }^{12}$

The earliest published reference to the Demoiselles was by a young poet and friend of Picasso's, André Salmon. He recognized its conceptual nature, comparing the painting's figures to numbers on a blackboard, and concluding that "This is the first appearance of the paintingequation." ${ }^{13}$ As Cubism became the most influential development in the visual arts of the $20^{\text {th }}$ century, the Demoiselles stood out more and more clearly as the century's greatest masterpiece. Table 1 confirms its privileged position among the works of art of the past century. Nude Descending a Staircase, No. 2, 1912

The movement of form in time inevitably ushered us into geometry and mathematics.

$$
\text { Marcel Duchamp }{ }^{14}
$$

In 1912 Marcel Duchamp executed a painting that was almost immediately interpreted as an attack on Cubism. Although the painting used the plastic forms and monochrome colors of Cubism, Duchamp had goals that differed considerably from those of Picasso and Braque, for as he later explained, he "wanted to create a static image of movement." ${ }^{15}$ In doing this, he drew on a number of influences, including the chronophotography of the French scientist Etiennes-Jules Marey and the photographic sequences of Eadweard Muybridge. ${ }^{16}$ Rather than views of a stable subject from different positions, as in Cubism, Nude Descending presents sequential views of a moving subject from a fixed vantage point. In addition, the painting built on Cubism's divorce of the painted image from the appearance of the object represented, by beginning to translate a 
human form into mechanical elements. Duchamp also took the unconventional step of inscribing the picture's title in block letters below the image.

Much of the importance of Nude Descending stems from two episodes, both of which involved group exhibitions. The first occurred in Paris in 1912, when Duchamp submitted his new painting to the Salon des Indépendants. It was rejected, in spite of the fact that Duchamp's brothers, Jacques Villon and Raymond Duchamp-Villon, were members of the jury. The two were delegated to ask Duchamp if he would change the painting's title, but he refused, and immediately retrieved the work. ${ }^{17}$

Nude Descending was exhibited in Paris later in the year, but the second important event in its history was a result of its inclusion in the Armory Show in New York in 1913. This was the now-legendary exhibition that introduced advanced European modern art to the American public. Although there was widespread outrage at the work of Matisse and others, the single painting that became the focus of the greatest ridicule in the popular press was Nude Descending. One widely-quoted critical remark described it as "an explosion in a shingle factory," and as Calvin Tomkins later explained, “To a great many visitors, the painting seemed to sum up everything that was arbitrary, irrational, and incomprehensible in the new art from Europe." ${ }^{18}$ By the close of the show, the young Marcel Duchamp was famous in the United States, a country he had never visited.

Although it was the second of these incidents that brought public attention to Duchamp, the first was perhaps more important in making Nude Descending a key work in Duchamp's career. Stung by the rejection of his painting by his fellow artists, including even his brothers, Duchamp appears to have resolved to go his own way, and to carry further the radical ideas that 
Nude Descending represented. ${ }^{19}$ As he proceeded to make increasingly extreme conceptual works, in retrospect Nude Descending appeared to have been an announcement of Duchamp's future agenda, which would fundamentally change the course of modern art. The importance of this was such that Arthur Danto has remarked that "the Nude explosively proclaimed a new era in art. ${ }^{20}$

\section{Unique Forms of Continuity in Space, 1913}

The higher art raises itself, the more distant it becomes from Nature.

$$
\text { Umberto Boccioni, } 1911^{21}
$$

Unique Forms of Continuity in Space was also made by a young artist who wanted to adapt Cubist forms to create a representation of motion. In 1909, the Italian painter Umberto Boccioni and several of his friends joined Futurism, which had been founded as a literary movement by the poet F. T. Marinetti. One of Marinetti's main concerns was the role of speed in modern life, so the Futurist painters took as a goal the visual representation of the sensation of movement.

Late in 1911 Boccioni visited Paris, where he saw the new Cubist techniques of Picasso and Braque, which he quickly incorporated into his paintings. Boccioni also suddenly developed an interest in sculpture. John Golding has argued that while in Paris "Boccioni, summing up the scene around him with an eye that was quick and competitive, saw that there was as yet no such thing as school of Cubist sculpture, and he sensed, very shrewdly, how he could best and most quickly make his mark." 22 In March of 1912 Boccioni wrote to a friend that "I am obsessed these days by sculpture. I think I can perceive a complete revival of this mummified art." ${ }^{23}$

Marinetti had introduced a novel conceptual practice in which polemical written 
manifestos accompanied, or even preceded, actual works of art. Following this model, in the spring of 1912, before he had begun making sculptures, Boccioni published a manifesto proposing a Futurist sculpture. To create the illusion of movement, he argued that the new approach must take account of the merging of an object with its surroundings. The problem Boccioni then confronted was how to do this in practice.

A year later, Boccioni presented 11 sculptures in an exhibition at a Paris gallery. Unique Forms was quickly recognized as the most important of the group, for its three-dimensional representation of power and speed. The surfaces of an advancing human figure are broken into parts, but rather than the straight lines of Cubism they are made of smooth curved planes, that appear to flow in the winds created by the figure's forward movement. The poet Guillaume Apollinaire, who was the most respected critic in Paris' advanced art world, praised Unique Forms as a "joyful celebration of energy."24

Boccioni's career as a sculptor lasted just this one year: Golding concluded that after making Unique Forms, "Boccioni seems to have realized that he had achieved the definitive masterpiece for which he longed." ${ }^{25}$ He was killed in 1916, while serving in the Italian army. World War I effectively ended the Futurist movement, which became influential more for its ideas than for its successful works of art. Yet John Golding declared that "Futurism did, however, produce one major masterpiece," as Unique Forms came to symbolize the achievement of the movement as a whole. ${ }^{26}$

Fountain, 1917

The readymade can be seen as a sort of irony, because it says here it is, a thing that I call art, I didn't even make it myself.

Marcel Duchamp, $1959^{27}$ 
In New York in 1917 Marcel Duchamp provoked one of the most far-reaching controversies in modern art. He purchased a porcelain urinal, painted on its rim the name R. Mutt, then submitted it under that fictitious artist's name, with the title Fountain, to the exhibition of the Society of Independent Artists. In spite of the fact that the society's policy was to exhibit any work submitted to it, the directors refused to exhibit Fountain. These actions triggered a critical debate over the meaning of art that continues today.

Fountain was not the first manufactured object Duchamp had made into art. He initially did this in 1913, by attaching a bicycle wheel to a stool. He then coined the term "ready-made" in 1915 to refer to this and other manufactured objects that he signed and titled. Fountain became the most celebrated of Duchamp's ready-mades, however, because of the debate that attended its rejection by the Independents.

In an article published in The Blind Man, a magazine published by Duchamp and a few friends at the time of the Independents exhibition, an editorial defended Fountain against the charge that it was not a work of art: "Whether Mr. Mutt with his own hands made the fountain or not has no importance. He CHOSE it. He took an ordinary article of life, placed it so that its useful significance disappeared under the new title and point of view - created a new thought for that object." ${ }^{28}$ This was the most extreme assertion that had ever been made of the primacy of the concept in art, for it proposed that the artist's craftsmanship could be eliminated altogether, and that a work of art could be made simply by the decision of the artist, because what mattered was the idea the work represented. Fountain also occasioned a debate over whether Duchamp was serious. In the same issue of The Blind Man, an article signed by a friend of Duchamp's noted that "there are those who anxiously ask, 'Is he serious or is he joking?' Perhaps he is both! 
Is it not possible?"29

After Fountain was removed from the premises of the Independents, Duchamp took it to Alfred Stieglitz's art gallery, where Stieglitz photographed it in front of a painting by Marsden Hartley. The original Fountain was later lost, but it lives on in written accounts of the Mutt case and in Stieglitz's famous photograph. These representations of the work are adequate, for as Octavio Paz observed of the ready-mades, "their interest is not plastic but critical or philosophical." 30

The issues raised in the Mutt case were so radical that for nearly four decades after 1917 the ready-mades had little impact on modern art. Like a time bomb, however, Duchamp's new genre exploded into the consciousness of the advanced art world in the mid-1950s, when Rauschenberg, Johns, and other artists began to incorporate real objects into their work. Since then Duchamp has become widely recognized as the single greatest influence on the advanced art of the second half of the twentieth century, as a succession of key contemporary artists have made works that continue to explore and expand the boundaries of art. Fountain has become the leading symbol of this legacy of Duchamp. ${ }^{31}$

\section{Monument to the Third International, 1919}

My monument is a symbol of the epoch. Unifying in it artistic and utilitarian forms, I created a kind of synthesis of art with life.

Vladimir Tatlin ${ }^{32}$

Vladimir Tatlin began his career as a painter, but on a trip to Paris in 1913 he was inspired by the new sculptures of Boccioni and Picasso, and he returned to Moscow as a sculptor. Tatlin had always believed that artists should rely not only on vision but on knowledge, and as a sculptor he devised novel forms by organizing miscellaneous found objects into three- 
dimensional constructions using formal geometric planning.

After the 1917 Revolution Tatlin became a leader of the movement to use art in the service of the new social order. In 1919, the Soviet government commissioned him to design a monument to the Third International, which Lenin had recently founded to promote global revolution. Tatlin's goal in doing this was to create a revolutionary new art form to celebrate the new revolutionary society.

Tatlin's Monument to the Third International was actually designed as a building that would house the Third International. It was to be a tower 1,300 feet high that would span the Neva river in Petrograd. The design was worked out by the end of 1919, and a model of it, about 20 feet tall, was exhibited the next year. ${ }^{33}$ The design embodied many layers of symbolism. The tower appeared to lean forward, befitting a progressive new form of government. The spiral shapes that dominated the design symbolized rising aspirations and triumph, while the use of two intertwined spirals symbolized dialectical argument and its resolution. Earlier, static governments were housed in static, immobile buildings, but the new government should have an active, mobile architecture. The lowest of the building's three levels, where the International's congress would meet, was to rotate fully on its axis once a year; the second level, which would contain the International's executive bodies, was to rotate once a month; and the highest level, which was reserved for newspaper and other information services to provide propaganda to the international proletariat, was to rotate once a day. The progressively smaller areas of the higher floors reflected the increasing concentration of power in smaller and more authoritative bodies. ${ }^{34}$ The monument was intended to have an immediate effect on anyone who entered it, for it was to be "a place of the most intense movement; least of all should one stand still or sit down in it, you must be 
mechanically taken up, down, carried away against your will." ${ }^{35} \mathrm{New}$ technology would help to create new art forms which would help to achieve new social objectives.

Tatlin claimed the design for the Monument could be carried out, but he was not an engineer, and it is unlikely that this dynamic new architecture could have been built. This was never attempted, but in the Soviet Union the model of the Monument, and photographs of the model after the original was lost, became popular symbols of the idea that advanced art could serve the purposes of the new Soviet society. Today the tower's image survives as the visual embodiment of the ambitious goals of early Communism, and the fact that it was never built only reinforces the symbolic value of the image in view of the disastrous consequences of those goals.

\section{Guernica, 1937}

In the panel on which I am working which I shall call Guernica, and in all my recent works of art, I clearly express my abhorrence of the military caste which has sunk Spain in an ocean of pain and death.

$$
\text { Pablo Picasso, } 1937^{36}
$$

On April 26, 1937, the Basque town of Guernica was destroyed by German bombers acting for General Franco. The day after the first photographs of the devastated town were published, on May 1, Picasso began working on a mural that was more than 25 feet long and 11 feet tall, by far the largest work he had ever made. He was working under extreme time pressure, for he had been commissioned to paint a mural for the Spanish pavilion at the Paris World's Fair, which was scheduled to open in early May. In the event the fair's opening was delayed, and the Spanish pavilion opened even later, but Picasso nonetheless created Guernica in just 10 weeks from the first sketches to the final canvas.

There is a remarkable body of documentation concerning the planning and execution of 
Guernica. More than 50 preparatory drawings for the painting have survived, most dated with the day they were made, and the painting was photographed at least ten times during the course of its execution by Picasso's companion Dora Maar, who was a professional photographer. This evidence has provided the basis for detailed scholarly analyses of the changing forms of the painting's figures both before and during the execution of the final work. Interestingly, however, the two scholars who have done the most intensive studies of Guernica have both stressed the unity of Picasso's initial overall conception of the painting. Picasso's first six sketches for the painting were done on May 1. Herschel Chipp remarked that these revealed that By the end of the first day of work, Picasso had performed a most remarkable feat: in a few hours he had formulated the basic conception of Guernica... The heroic bull towering over the scene of chaos, the agonized horse writhing on the ground, and screaming toward the sky, and the female observer surveying the carnage - all were to remain an integral part of the final painting, five or six intervening weeks of continual change notwithstanding. ${ }^{37}$

Rudolf Arnheim made a similar observation, of a central concept that persisted from beginning to end:

While the work was going on, there were changes of emphasis and proportion, and there were many experiments in trying to define the content by working out its shape. A germinal idea, precise in its general tenor but unsettled in its aspects, acquired its final character by being tested against a variety of possible visual realizations. ${ }^{38}$

Before the modern era, the importance of art depended in large part on its subject matter: the greatest paintings had to treat religious themes, or show classical heroes in triumph. This changed with the advent of modern art, as the Impressionists and their successors painted nature, or scenes of everyday life. Cubism then retreated into even more restricted subject matter, with 
images made up almost exclusively of studio props. Guernica was a dramatic departure, for it demonstrated that the most advanced forms of modern art, that had previously been used only for private expression, could be used to make a large-scale public work that dealt forcefully with the most important issues facing modern society. ${ }^{39}$ In doing this it became an inspiration for all modern artists who wanted their work to make social and political statements.

\section{Just what is it that makes today's homes so different, so appealing?, 1956}

Contemporary art reacts slowly to the contemporary stylistic scene. How many major works of art have appeared in the twentieth century in which an automobile figures at all?

\section{Richard Hamilton, $1962^{40}$}

In London in the early 1950s, Richard Hamilton was a member of the Independent Group, made up of young artists and critics who wanted to create an art that reflected recent developments in popular culture and technology. In 1956 the group organized an exhibition, titled "This is Tomorrow," at the Whitechapel Art Gallery, and Hamilton agreed to make a poster for the show.

Hamilton went about his task systematically. He began with a list of 15 categories of interest: Man, Woman, Humanity, History, Food, Newspapers, Cinema, TV, Telephone, Comics, Words, Tape recording, Cars, Domestic appliances, and Space. Hamilton, his wife, and another artist then searched through piles of magazines, many of which had been brought back from the United States by a fellow Independent Group member, cutting out illustrations that could represent the categories on Hamilton's list. Hamilton then selected one image for each category, and combined them into a small collage, which showed a male bodybuilder and a female pin-up in a fictitious living room furnished with a wide range of consumer goods and advertising logos. 
The work's title was itself a caption from a discarded photograph.

Just what is it? is a complex work, made up of many separate images, a number of which have multiple meanings. So for example the ceiling is actually a photograph of the Earth made from outer space, a lampshade is made of the Ford insignia, and a carpet is a detail of a photograph of hundreds of people on a beach. In a prominent position, the word "Pop" appears in large letters on a Tootsie roll pop held by the bodybuilder. Commercial products abound: a canned ham is displayed on a coffee table, a framed comic book hangs on the wall, a tape recorder sits on the floor, and a theatre marquee seen through a window advertises The Jazz Singer.

Hamilton and his friend Eduardo Paolozzi were pioneers of British Pop art, which preceded its American relative. In general, British Pop was subtler and more complex visually than American Pop, but the broad appeal of the leading Americans lay in large part in the brashness, simplicity, and large size of their works. ${ }^{41}$ In spite of the fact that Warhol, Lichtenstein, Oldenburg, and other American Pop artists would overshadow Hamilton and his British colleagues, Just what is it?, made years before Warhol had begun to reproduce magazine photographs or Lichtenstein had begun to mimic comic strips, has justifiably been described as "an icon of early Pop," for its prophetic presentation of the commercial images that would transform advanced art in New York in the early ' 60 s. ${ }^{42}$

Spiral Jetty, 1970

I think the major issue now in art is what are the boundaries. For too long artists have taken the canvas and stretchers as given, the limits.

$$
\text { Robert Smithson, } 1969^{43}
$$


The 1960s began an era of pluralism in art that has continued to the present, marked not only by the proliferation of styles but also by the creation of a number of new artistic genres. In one of these new genres, Robert Smithson created a rare synthetic masterpiece that has become the most frequently illustrated work in the entire history of American art.

Smithson was a leader of the Earth art movement, in which a number of young artists decided not only to place their art in the landscape, away from galleries and other traditional settings for art, but to use the landscape itself to make their art. Smithson was the first to use the term "earthwork" to refer to the objects he and his colleagues created in remote areas. ${ }^{44}$ In Smithson's mature projects, Earth art became a complex conceptual activity that consisted not only of the construction of large-scale monuments from earth and stone, but also involved written texts, "non-sites" (indoor earthworks), films, and extensive documentation, in the form of photographs and maps.

Spiral Jetty is located in an isolated area of Utah's Great Salt Lake. After Smithson had planned its form, and staked out its boundaries, the 1,500-foot-long jetty was created over a period of three weeks by a five-man crew using a tractor and two dump trucks to move more than 6,500 tons of mud, salt crystals, and rocks. The construction of the jetty was filmed by a professional photographer according to a detailed plan Smithson had prepared. Two years later Smithson published an essay on the jetty, that in the span of just ten pages ranges from the origins of Smithson's interest in salt lakes to the structure of the film Smithson made about it, passing through references to more than a dozen academic disciplines, and comparisons of the jetty's shape to a dozen other objects, both natural and artificial. ${ }^{45}$

In Spiral Jetty, Smithson managed to incorporate a remarkable number of issues that were 
central to the advanced art of the 1960s. The most general unifying feature of the art of the period was its conceptual orientation, and Smithson made his work the focal point of an enormously varied body of ideas. The shapes of all his works were simple, drawing on Minimalist sculpture, the leading movement of the mid-60s. Yet in Spiral Jetty Smithson made his own adaptation of Minimalism, with a larger scale and an elegant curved shape. The remote location of the Jetty drew on the anti-commercial, anti-gallery sentiment that was shared by many young artists at the time. The base materials used to make the Jetty, and the difficulty of viewing it, served further to defy the traditional methods and presentation of fine art. Smithson's complex written text reflected a vital tradition of conceptual art, in using language to accompany objects, that dated back to Futurism. The extensive use of photography and film to present Jetty to a broader public reflected a trend of the 1960s to use mechanical reproduction as part of, or in lieu of, works of art.

Smithson was killed in 1973, at the age of 35, when the small plane from which he was photographing the staked-out plans for a new work in Amarillo, Texas, crashed into a hillside. His premature death, in the process of making his art, added poignancy to accounts of the brief life of the brilliant young artist who created monumental works in remote places. But Smithson had already succeeded in creating new forms of art by breaking old boundaries, physical as well as intellectual, and he had guaranteed continuing attention to these innovations by creating the most indispensable masterpiece in American art.

\section{$\underline{\text { Creative Careers }}$}

This century's most practiced creators of legendary works have, of course, been Picasso and Duchamp.

David Sylvester, $1995^{46}$ 
As the preceding discussions have shown, all eight of the works of art considered in this paper were made by conceptual innovators, whose innovations embody new ideas that the artists formulated before executing their works. Earlier research has found that the most important conceptual innovations, which make radical departures from established conventions, tend to occur early in artists' careers, before they have become constrained by fixed habits. Table 3 largely supports this generalization. Thus the median age of the artists when they executed these eight works was 31.5 years. Seven of the eight works were made by artists aged 35 or younger, and the most important of the eight was made by Picasso when he was 26 . One of these works was made by an older artist, as Picasso produced Guernica at 55, but he had made his greatest innovation nearly 30 years earlier.

An interesting feature of conceptual creativity is that important conceptual innovations can be made by relatively unimportant artists. Thus in a number of cases fine art has produced one-hit wonders - artists who formulated a single important idea, and embodied it in an individual work that consequently dominates their careers. ${ }^{47}$ Table 4 shows that three of the eight works considered here clearly dominate the careers of their makers, as the Monument to the Third International, Just what is it?, and Spiral Jetty all account for at least $60 \%$ of the total illustrations of these three artists' work in the 33 textbooks surveyed. Yet although this phenomenon is possible, it is of course not necessary. It is striking that four of the eight works considered here were made by two artists who rank among the very greatest figures in modern art: Picasso is by far the greatest artist of the past century, and Duchamp ranks third, after only Picasso and Matisse, among the greatest artists of the $20^{\text {th }}$ century. ${ }^{48}$ Both Picasso and Duchamp are archetypal cases of the versatile conceptual artists who have become a prominent feature of 
twentieth-century art. ${ }^{49}$

\section{Conceptual Creativity}

To paint, then, in the twentieth century requires no elaborate skill in drawing, no stock of conventional knowledge, but sensibility, feeling, and a strong impulse to creation. The painter has ceased to be a craftsman or a learned man; he is a creator in the pure sense of the philosophers.

$$
\text { Meyer Schapiro, } 1957^{50}
$$

The eight works considered her all represent important conceptual innovations in the art of the twentieth century. Some of the century's most important artistic movements are not represented among these landmark works: in some cases this is because experimental artists produced large bodies of work from which no individual landmarks emerged, while in other cases conceptual artists embodied an innovation in several major works that competed with each other, so that none emerged as a dominant statement. Some of the works examined here do symbolize entire movements, as Boccioni's Unique Forms stands for Futurism, Hamilton's Just what is it? represents Pop art, Smithson's Spiral Jetty stands for Earth art, and most notably, Picasso's Demoiselles represents Cubism.

Conceptual innovation is in no way a new or recent development; it can in fact be traced back at least as far as one of the most important early developments in the history of Western art, the introduction of linear perspective, which made Masaccio's Tribute Money one of the most frequently reproduced paintings ever produced. ${ }^{51}$ What is new in the twentieth century, however, is the extremity of conceptual innovation, as the importance of the artist's idea has been increased relative to the significance of the artist's execution of the work. Thus among the works considered here, Duchamp's Fountain involved no work of the artist's hand other than a 
signature, Tatlin's Monument survives only in photographs of a model that was built by Tatlin and several assistants, and Spiral Jetty was produced by construction workers following Smithson's design and direction. The first two of these today exist only in photographs, while the third was invisible for nearly 30 years under the water of Great Salt Lake, and is still seen almost exclusively in photographs, for even after a potential viewer travels to Golden Spike National Historic Site, access to Spiral Jetty requires a 16-mile trip on a gravel road that has many large lava rocks embedded in it. ${ }^{52}$

Even in cases in which an artist's new ideas are complemented by virtuosity in execution, the great value placed on rapid conceptual innovation differentiated the twentieth century from earlier periods with respect to artistic practice. So far example the eminent critic David Sylvester observed that Picasso, who was recognized from the beginning of his career for his extraordinary draftsmanship, was “a kind of artist who couldn't have existed before this century, since his art is a celebration of this century's introduction of a totally promiscuous eclecticism into the practice of art." ${ }^{, 53}$ Only in the twentieth century did the increased value placed on sustained change in art allow a painter to make frequent, abrupt stylistic shifts without fear of alienating his audience, and Picasso, the greatest painter of his era, made more frequent, abrupt shifts than any of his peers. ${ }^{54}$ And only in the twentieth century would a ranking of the eight most important individual works of art include not only the traditional genres of painting and sculpture but no less than three other genres - readymade, collage, and earthwork - that did not even exist when the century began. In 2001, Arthur Danto observed that "We are living in a conceptual art world." 55 The present study suggests that we have in fact been living in a conceptual art world for nearly a century. 
$\underline{\text { Footnotes }}$

I thank Robert Jensen for discussions.

1. Clement Greenberg, The Collected Essays and Criticism, Vol. 4 (Chicago: University of Chicago Press, 1993), p. 118.

2. Meyer Schapiro, Worldview in Painting - Art and Society (New York: George Braziller, 1999), p. 204.

3. E.g. David Galenson, "Who Are the Greatest Living Artists? The View from the Auction Market,” NBER Working Paper 11644 (September 2005).

4. Michel Sanouillet and Elmer Peterson, eds., The Writings of Marcel Duchamp (New York: Da Capo Press, 1973), p. 138.

5. David Galenson, Artistic Capital (New York: Routledge, 2006), Table 1.3, p. 7; Table 2.2, p. 26; Table 8.3, p. 129; Galenson, "One-Hit Wonders: Why Some of the Most Important Works of Modern Art Are Not by Important Artists," Historical Methods, Vol. 38, No. 3 (Summer 2005), Tables 8, 12, pp. 108-110; Galenson, "The Greatest Artists of the Twentieth Century," NBER Working Paper 11899 (2005).

6. These books are listed in the appendix to Galenson, "The Greatest Artists of the Twentieth Century."

7. Guillaume Apollinaire, The Cubist Painters (Berkeley: University of California Press, 2004), p. 13.

8. George Heard Hamilton, Painting and Sculpture in Europe, 1880-1940 (Harmondsworth: Penguin, 1967; John Russell, The Meanings of Modern Art (New York: Museum of Modern Art, 1981), p. 97.

9. John Richardson, A Life of Picasso, Vol. 1 (New York: Random House, 1991), pp. 41114.

10. William Rubin, Hélène Seckel, and Judith Cousins, Les Demoiselles d'Avignon (New York: Museum of Modern Art, 1994), pp. 14, 119.

11. William Rubin, ed., Pablo Picasso: A Retrospective (New York: Museum of Modern Art, 1980).

12. John Richardson, A Life of Picasso, Vol. 2 (New York: Random House, 1996), pp. 45, 83. 
13. Beth Gersh-Nesic, The Early Criticism of André Salmon (New York: Garland, 1991), p. 40.

14. Pierre Cabanne, Dialogues with Marcel Duchamp (New York: Da Capo Press, 1987), p. 31.

15. Cabanne, Dialogues with Marcel Duchamp, p. 30.

16. Cabanne, Dialogues with Marcel Duchamp, p. 34; Sanouillet and Peterson, The Writings of Marcel Duchamp, p. 124.

17. Calvin Tomkins, Duchamp (New York: Henry Holt, 1996), pp. 81-83.

18. Tomkins, Duchamp, pp. 116-17.

19. Calvin Tomkins, The Bride and the Bachelors (New York: Viking press, 1965), p. 22.

20. Arthur Danto, The Madonna of the Future (Berkeley: University of California Press, 2001), p. 179.

21. Ester Coen, Umberto Boccioni (New York: Metropolitan Museum of Art, 1988), p. 234.

22. John Golding, Boccioni's “Unique Forms of Continuity in Space” (Newcastle: University of Newcastle upon Tyne, 1972), p. 14.

23. Golding, Boccioni’s “Unique Forms of Continuity in Space”, p. 14.

24. Guillaume Apollinaire, Apollinaire on Art (Boston: MFA Publications, 2001), p. 321.

25. Golding, Boccioni’s “Unique Forms of Continuity in Space”, p. 28.

26. Golding, Boccioni’s “Unique Forms of Continuity in Space”, p. 3.

27. Dawn Ades, Neil Cox, and David Hopkins, Marcel Duchamp (London: Thames and Hudson, 1999), p. 151.

28. Tomkins, Duchamp, p. 185.

29. Joseph Masheck, ed., Marcel Duchamp in Perspective (Englewood Cliffs: Prentice-Hall, 1975), p.71.

30. Masheck, Marcel Duchamp in Perspective, p. 84.

31. Recent evidence of this was provided by an English survey of 500 artists, curators, critics, and dealers, commissioned by the sponsor of the Turner Prize. Fountain was voted the most influential work of modern art, ahead of Les Demoiselles d'Avignon, which placed 
second. The surprising success of Fountain in the poll was attributed to overwhelming support from the artists who responded; Charlotte Higgins, "Work of art that inspired a movement... a urinal," Guardian (Dec. 2, 2004).

32. Christina Lodder, Russian Constructivism (New Haven: Yale University Press, 1983), p. 65.

33. Lodder, Russian Constructivism p. 60.

34. John Milner, Vladimir Tatlin and the Russian Avant-Garde (New Haven: Yale University Press, 1983), Chap. 8.

35. Lodder, Russian Constructivism p. 56.

36. Alfred Barr, Picasso: Fifty Years of His Art (New York: Museum of Modern Art, 1946), p. 202.

37. Herschel Chipp, Picasso's Guernica (Berkeley: University of California Press, 1988), p. 78.

38. Rudolf Arnheim, The Genesis of a Painting: Picasso's Guernica (Berkeley: University of California Press, 1962), pp. 134-35.

39. Hamilton, Painting and Sculpture in Europe, 1880-1940, pp. 458-59.

40. Richard Hamilton, Collected Words, 1953-1982 (London: Thames and Hudson, 1982), p. 35 .

41. Steven Madoff, ed., Pop Art (Berkeley: University of California Press, 1997), p. xvii.

42. Marco Livingstone, Pop Art (New York: Harry N. Abrams, 1990), p. 36.

43. Jack Flam, ed., Robert Smithson: The Collected Writings (Berkeley: University of California Press, 1996), p. 175.

44. Flam, Robert Smithson, p. 68.

45. Flam, Robert Smithson, p. 143-53.

46. David Sylvester, About Modern Art (New York: Henry Holt, 1997), p. 353.

47. Galenson, “One-Hit Wonders”, pp. 101-17.

48. Galenson, "The Greatest Artists of the Twentieth Century," Table 2. 
49. David Galenson, "And Now for Something Completely Different: The Versatility of Conceptual Innovators," NBER Working Paper xxxx (2006).

50. Schapiro, Worldview in Painting, p. 193.

51. Robert Jensen, "Anticipating Artistic Behavior: New Research Tools for Art Historians," Historical Methods, Vol. 37, No. 3 (2004), p. 144.

52. Galenson, Artistic Capital, pp. 126, 253.

53. Sylvester, About Modern Art, p. 30.

54. Galenson, "And Now for Something Completely Different."

55. Arthur Danto, Unnatural Wonders (New York: Farrar, Straus, and Giroux, 2005), p. 99. 
Table 1: Most Important Works of Art of the Twentieth Century, in Chronological Order

\begin{tabular}{|l|c|c|}
\hline Artist, title & Date & Location \\
\hline \hline Pablo Picasso, Les Demoiselles d'Avignon & 1907 & New York \\
\hline Marcel Duchamp, Nude Descending a Staircase, No. 2 & 1912 & Philadephia \\
\hline Umberto Boccioni, Unique Forms of Continuity in Space & 1913 & New York \\
\hline Marcel Duchamp, Fountain & 1917 & -- \\
\hline Vladimir Tatlin, Monument to the Third International & 1919 & -- \\
\hline Pablo Picasso, Guernica & 1937 & Madrid \\
\hline $\begin{array}{l}\text { Richard Hamilton, Just what is it that makes today's homes } \\
\text { so different, so appealing? }\end{array}$ & 1956 & Tübingen \\
\hline Robert Smithson, Spiral Jetty & 1970 & Great Salt Lake \\
\hline
\end{tabular}

Source: see text. 
Table 2: Ranking of Works

\begin{tabular}{|l|c|c|}
\hline Artist, title & $\mathrm{N}$ & \% of total books \\
\hline \hline $1 \quad$ Picasso, Les Demoiselles d'Avignon & 28 & 85 \\
\hline $2 \quad$ Tatlin, Monument to the Third International & 25 & 76 \\
\hline $3 \quad$ Smithson, Spiral Jetty & 23 & 70 \\
\hline $4 \quad \begin{array}{l}\text { Hamilton, Just what is it that makes today's homes so } \\
\text { different, so appealing? }\end{array}$ & 22 & 67 \\
\hline $5(\mathrm{t})$ Boccioni, Unique Forms of Continuity in Space & 21 & 64 \\
\hline $5(\mathrm{t})$ Picasso, Guernica & 21 & 64 \\
\hline $7 \quad$ Duchamp, Fountain & 18 & 55 \\
\hline $8 \quad$ Duchamp, Nude Descending a Staircase, No. 2 & 16 & 48 \\
\hline
\end{tabular}

Source: This and subsequent tables are based on the data set created for this study. See the text for a description. 
Table 3: Artists' Ages at Time of Execution of Most Important Works

\begin{tabular}{|c|c|}
\hline Artist, title & Age \\
\hline 1 Picasso, Demoiselles & 26 \\
\hline 2 Tatlin, Monument & 35 \\
\hline 3 Smithson, Spiral Jetty & 32 \\
\hline 4 Hamilton, Just what is it? & 34 \\
\hline 5(t) Boccioni, Unique Forms & 31 \\
\hline 5(t) Picasso, Guernica & 55 \\
\hline 7 Duchamp, Fountain & 30 \\
\hline 8 Duchamp, Nude Descending & 25 \\
\hline
\end{tabular}


Table 4: Illustrations of Most Important Works as Percentage of Artists' Total Illustrations in Books Surveyed

\begin{tabular}{|ll|c|c|c|}
\hline Artist, title & $\mathrm{N}$ & Artist's total illustrations & $\%$ \\
\hline \hline $1 \quad$ Picasso, Demoiselles & 28 & 395 & 7 \\
\hline $2 \quad$ Tatlin, Monument & 25 & 42 & 60 \\
\hline $3 \quad$ Smithson, Spiral Jetty & 23 & 34 & 68 \\
\hline $4 \quad$ Hamilton, Just what is it? & 22 & 34 & 65 \\
\hline $5(\mathrm{t})$ & Boccioni, Unique Forms & 21 & 55 & 38 \\
\hline $5(\mathrm{t})$ & Picasso, Guernica & 21 & 395 & 5 \\
\hline $7 \quad$ Duchamp, Fountain & 18 & 122 & 15 \\
\hline $8 \quad$ Duchamp, Nude Descending & 16 & 122 & 13 \\
\hline
\end{tabular}

